\title{
Bittersweet: The Effects of Psychological Trauma in One's Stages of Life
}

\author{
Asallie, C. \\ English for Creative Industry, Faculty of Letters, Petra Christian University, Siwalankerto 121-131, Surabaya \\ 60236, East Java, INDONESIA \\ Emails:m11413019@john.petra.ac.id
}

\begin{abstract}
The project is about the development of a screenplay which explores the psychological problem of the main character. The creative work revolves around the traumatic experiences that result in the main character's insecurity. The story shows how the main character, Jieun, is haunted by the pressure she used to have when she was a kid, causing her to feel insecure when she finally turns into an adult. The theory used for this creative work is Erik Erikson's theory of Psychological Stages of Development which tells about how something that happened in the past could affect things that are happening in the present. The theory helps the writer achieve the result of the creative work, making the creative work have distinct characteristic. Because of her insecurity, Jieun fails in fulfilling her need to build a relationship. Finally, she regains her feeling of security as she goes back to and connect with her family.
\end{abstract}

Key words:

Trauma, Insecurity, Erik Erikson, Dilemma, Psychological Development.

\section{INTRODUCTION}

As the time comes for me to do my project, I choose to explore more of my ability to write a screenplay. I decided that I want to make a story that is real enough for the audience to understand, perceive, and imagine. I have liked writing since I was in middle school, and during that time, I wrote a few small works only to save it for myself. Throughout the years of creative writing learning process, I realize that to turn a simple theme into something that could occupy people's mind is a powerful and interesting thing to do through a story, which leads to why I choose love as the subject of my project to see how deep I can go through a simple topic in writing.

The work that I plan to write is a screenplay which in the end will be produced as a feature film. According to the Academy of Motion Picture Arts and Sciences, the American Film Institute, and the British Film Institute, a feature film runs for 40 minutes or longer. Genre wise, according to Christy Tillery French, a feature film is a plot-driven fictional works written with the intent of fitting into a specific literary genre, in order to appeal the readers and fans already familiar with the genre (French, 2013). Being a fiction, this creative work also belongs to the genre drama. Drama is a genre that relies on the emotional and relational development of realistic characters (Buffam, 2011). Just like the said definition, this creative work will focus on the emotional and relational development of the main character, how the main character grows emotionally and how the main character grows in the relationship aspect.

I want to write this screenplay because I want to try expressing the feeling of someone who is trying to hold everything together. In this story, my main character, Jieun, is someone who is struggling emotionally. She has two friends, Jihoon and Sohyun, and is torn between following her heart, as she actually has a crush on Jihoon, and following her parent's vision which was pushed into her ever since she was a child. This makes her abandon her personal life, as she tries to make her family proud, which she believes could be achieved through her getting a job and being able to pay for her siblings' tuition and school cost. At the end, the main problem is not love anymore. I want people to know a person's personal struggle aside from their love life as well. I want people who have experienced it to know that they are not alone, and there are also a lot of people with the same problem.

As someone experiencing a lot of dilemma in my life, it gets to my mind that a lot of times, people are facing two different paths in their life. Whether it starts from choosing on what to eat, what to do, where to go, or going to much bigger decision such as where to go in college, whether to continue a master's degree or not, etc. As life constantly brings choices to people, I think the topic would fit perfectly to create such conflict. As Robert Sternberg says, all love is composed of three elements: intimacy, passion, and commitment. (Sternberg, 1986) Love will not work when it 
loses one of the elements. Whereas in my creative work, the main character loses not only one, but two aspects of these elements: passion and commitment. As the main character should choose what is obvious, I want to explore more of her doubts, what makes her not choosing the obvious path as expected, thus, recognizing that the human mind is not easy thing to understand, especially with some psychological problem that my main character has.

The other problem I would like to address in this artwork is how to overcome all the overflowing feelings of being heart broken caused by own trauma. To fall in love is a complicated thing already, let alone having a heart broken due to a psychological trauma. Both topics affect people in different ways, and having both topics in the artwork will give people more specific information about both topics since there are a lot of things happening when it goes to this topic.

The problems stated in this screenplay revolves around the topic of trauma, insecurity, and doubt. These topics are shown in the main character who is given the name Jieun. In this story, Jieun is torn between her decision to chase "happiness" for herself, and her father's words and her responsibility as the oldest sibling and the first child of the family..

The purpose of this screenplay is to portray a side that not many people follow in real life, as well as showing that how Jieun copes with her heartbreak and with her decision as well. As the big theme in this screenplay is trauma, I try to kind of "cover" Jieun's hardships through her relationship with her friends and with a man she loves. In order to hide her one side, I put Jieun in a position where all of her friends are looking for her the first time when they encounter problems. However, they do not realize that Jieun herself hide her traumas, insecurities, and doubts from all people, including her friends.

For this screenplay, I am using a theory from Erik Erikson called Psychological Stages of Development. The theories explain about few stages in a human's psychological development, and how failure in achieving the stages will affect the next stage differently. According to Erik Erikson, people in general experiences eight psychological stages, which consist of: trust vs mistrust, autonomy vs shame $\&$ doubt, initiative vs guilt, industry vs inferiority, identity vs role-confusion, intimacy vs isolation, generativity vs stagnation, and the last one is integrity vs despair. During each stage, a person experiences a psychosocial crisis which could have a positive or negative impact on the personality development.

As in this story, Jieun's stage now belongs to the sixth stage as she is aged 26 years old in the story. She is in the stage of looking for intimacy and long relationship, as what she desires from her relationship with Jihoon, a man whom my main character loves. However, at the same time she is also facing loneliness due to her own principal which is the result of her problematic past where her father always pushed her to do her best in everything, not to focus on other things first and her father also added her siblings as extra responsibility for her. Her father's act made Jieun felt uncomfortable being herself, she became scared in facing failures, and the shadows of her father and siblings are haunting her a lot. Jieun's desire to have an intimacy is not fulfilled and it results in her isolation shown in first half of the story where she is lying to her interviewer about where she is, not taking care of herself and her apartment, also she is lacking of sense of self as seen in the first half of the story too when she is putting Jihoon's needs first before her own needs.

Also, her problematic experience caused by her father also affects how she sees the world in the present, how she face everything with Jihoon and takes decision about Jihoon and her own life. The creative work proves that Erikson's theory is true, that what happened on the earlier stage could affect what happens later in life.

\section{CONCEPT AND ANALYSIS OF THE CREATIVE WORK}

\subsection{Modes of Expression}

The genre I am using for this creative work is drama. The main appeal of this genre is that it relies heavily on character development. Dramatic themes play a large role in the plot as well. Often, these dramatic themes are taken from intense, real life issues. Whether heroes or heroines are facing a conflict from the outside or a conflict within themselves, drama film aims to tell an honest story of human struggles.

For this work I am working, I am inspired by Douglas Sirk's famous romance work All That Heaven Allows. The famous work tells about an upper-class widow, Cary Scott, who falls in love with much younger nurseryman, Ron Kirby. The couple love each other so much, yet Cary's kids 
does not allow their mother's relationship with Ron as they think that it is not worthy as Cary is a rich widow and Ron is just a poor nurseryman. Not only that, Cary's friends also forbid the relationship to happen because of the same reason. Here in the film, the story does not only revolves around the romance itself but also the problems around the kids and Cary's friends. Not to mention that Cary and Ron try their hardest for the sake of their relationship.

The story of All That Heaven Allows is not only based on love and romance, yet also talks about other aspects of life, that even though two people love each other, they are not always able to be together that easy because of some barriers: Cary's kids, Ron's status, and their social judgement. The same goes with my work, my works does not talk about love only, but also the problems around it.

\subsection{Genre Codes and Conventions}

In this section I would like to discuss further about genre codes and conventions that I use for this work. For the genre codes, I am referencing from Daniel Dercksen's article Genre and Genre Conventions written in 2015 for writingstudio.co.za.

\begin{tabular}{|c|l|l|}
\hline $\begin{array}{c}\text { Story } \\
\text { Elements }\end{array}$ & \multicolumn{1}{|c|}{ Conventions of Drama } & \multicolumn{1}{|c|}{$\begin{array}{c}\text { Conventions of My } \\
\text { Creative Work }\end{array}$} \\
\hline Main character & $\begin{array}{l}\text { Believable that the audiences } \\
\text { characters. }\end{array}$ & $\begin{array}{l}\text { Mymathize the character in this } \\
\text { creative work experiences } \\
\text { hardships during her } \\
\text { everyday life, making her } \\
\text { believable. A lot of people } \\
\text { could relate to her condition } \\
\text { and problems My main } \\
\text { character pretty much } \\
\text { represents a lot of people in } \\
\text { real life in term of her } \\
\text { lifestyle and her problems. }\end{array}$ \\
\hline $\begin{array}{l}\text { Number of } \\
\text { characters }\end{array}$ & $\begin{array}{l}\text { Usually consists of minimum } \\
\text { one main protagonist and an } \\
\text { antagonist. }\end{array}$ & $\begin{array}{l}\text { My creative work consists } \\
\text { of one protagonist only. The } \\
\text { story which is told in the } \\
\text { creative work revolves } \\
\text { around this girl named } \\
\text { Jieun. Jieun }\end{array}$ \\
\hline Conlifct & $\begin{array}{l}\text { The main conflict on this } \\
\text { genre usually involves } \\
\text { emotional and or physical } \\
\text { hardships, illness, human } \\
\text { emotion, tragedy, romance } \\
\text { and or friendship, }\end{array}$ & $\begin{array}{l}\text { The main conflict of this } \\
\text { creative work involves my } \\
\text { main character's emotional } \\
\text { hardship as she used to be } \\
\text { emotionally abused by her } \\
\text { father. She was pressured to } \\
\text { do things perfectly. She was } \\
\text { not allowed to meet boys } \\
\text { even though the boys were } \\
\text { just her friends. Her circle } \\
\text { of friend was limited by her } \\
\text { father, making her a little } \\
\text { antisocial, affecting her } \\
\text { friendship life in the future. }\end{array}$ \\
\hline $\begin{array}{l}\text { Usually, a goal does not } \\
\text { come easily for the main } \\
\text { character, between the } \\
\text { struggle to get that goal, } \\
\text { main character would also } \\
\text { face difficulties coming from } \\
\text { my character. My main } \\
\text { character's goal originally is } \\
\text { to achieve love and career at } \\
\text { the same time. However, her } \\
\text { hardships in the past, and }\end{array}$ \\
\hline
\end{tabular}




\begin{tabular}{|l|l|l|}
\hline different aspects. & $\begin{array}{l}\text { the pressure she received } \\
\text { from her father make her } \\
\text { choose to stick with her } \\
\text { principal, and puts herself } \\
\text { aside. }\end{array}$ \\
\hline Tone & $\begin{array}{l}\text { The overall tone of this } \\
\text { work is set to follow my } \\
\text { main character. The } \\
\text { The tone usually follows the character and the } \\
\text { efforts and struggles. }\end{array}$ & $\begin{array}{l}\text { storyline and the plot is } \\
\text { following my main } \\
\text { character's emotional } \\
\text { hardships and journey, also } \\
\text { revealing the reason behind } \\
\text { her actions. Audience would } \\
\text { also be taken to flashbacks } \\
\text { which show my main } \\
\text { character's past and how her } \\
\text { pastaffects her }\end{array}$ \\
\hline
\end{tabular}

\subsection{Outline of the Creative Work}

\subsubsection{Theme}

For this creative work, I am using the theme love. Jieun is experiencing the same thing in the story. The love story will be portrayed from Jieun's point of view, from Jieun's side with Jieun's way of thinking and principles as well. I want my audience to be able to feel what Jieun feels and to be able to relate to Jieun's story as love is a feeling we usually feel on a daily basis, let it be love for God, for teachers, for friends, for lovers, and for parents. She falls in love with someone who has different principles with her. She could have changed her mind and principles, but instead, she chooses the love for her family instead of for her crush. She chooses to focus on her principal and way of living given by her father than to pursue her love life. Through this work, I want to encourage people to not only go for a relationship blindly. We should consider ourselves first in all ways. We may all need a little pull to get ourselves out of the situation, yet it is okay too to take some times like Jieun do and pursue what is more important for us.

\subsubsection{Pitch}

1. Jieun falls in love with Jihoon, a good friend of hers, but at the same time, she feels the pressure to also focus on her career.

2. Jieun tries to care for both her career and love life equally, but at the same time also is torn by what her father had told her a long time ago about to put love second, due to family problems.

3. She realizes that she cannot has it all and she decides to sacrifice her love life and go to pursue her career instead of keep craving for happiness from someone else.

\subsubsection{Synopsis}

This creative work is about a girl named Jieun who has been in love with her friend for some times. However, it is then revealed that Jihoon actually stands in a different principal than her. The principal differences force Jieun to realize that she cannot be with Jihoon. Instead of her, Jihoon is dating Jieun's best friend Sohyun. The artwork will tell the audience about how Jieun copes with her decision which causes her heartbreak and how she gets over it as time passes.

\subsubsection{Step Outline}

1. Jieun is walking through a rather small and ugly alley when her cellphone rings.

2. Jieun sees the caller ID and takes the call.

3. Jieun implicitly tells the caller that she is currently in another place with a desk and a note, more over, she is lying to the caller that she is in an office room right now. 
4. Jieun's expression turns bitter as the caller announced that she is failing to get the job she wants.

5. Jieun continues walking home and arrives home in her tiny messy apartment.

6. Jieun is putting her stuffs messily, making her apartment even messier as a call from her father comes.

7. She doesn't dare to tell her father that she doesn't get the job.

8. Not too long after her Father called, Jihoon calls her.

9. Jieun is answering Jihoon's phone call while looking inside her fridge which only has soju, ramyeon and some instant food inside.

10. Jihoon asks to meet. Jieun agrees to meet. They agree to meet in a café near Jieun's apartment.

11. Jieun checks her appearance before meeting Jihoon. She is struggling to find something to wear. It is obvious that she wants to look best for Jihoon.

12. A flashback from the time Jieun was 9 came in. The flashback showed that even from a young age, Jieun is already pressured by her father to do everything perfectly.

13. They are meeting in a café near Jieun's apartment.

14. Jihoon starts to tell Jieun his problems with Sohyun. They are about to get married yet Sohyun is still not sure with Jihoon. He needs to convince Sohyun that he is the one for her and Jihoon somehow feels frustrated because his father is also sick and kind of pressuring him to settle down as soon as he can.

15. Jieun listens carefully.

16. Jieun is convincing Jihoon that Sohyun really loves him. This time, with a quick squeeze on Jihoon's hand, she assures Jihoon that he and Sohyun will be alright.

17. After meeting Jihoon in the afternoon, Jieun is meeting Sohyun at night. They are meeting in their usual place, Jieun's rooftop.

18. Jieun is already in the rooftop waiting for Sohyun when the said girl suddenly shocks Jieun from behind before sitting next to Jieun.

19. They first talk about how they both are doing before Jieun jumps into the conversation about Sohyun and Jihoon. Sohyun gives her point of view from the problem, how Jihoon has been quite selfish towards her all these times. However, the more Jieun tries to defend Jihoon, the more Sohyun is unsure about her relationship with Jihoon.

20. A flashback to the time when Jieun was 12. The flashback shows that she is not allowed to like boys around her age and is told to just focus in her studies.

21. Jieun tells Sohyun to give Jihoon a second chance. Sohyun said that she will consider Jieun's suggestion. Then they start talking more about their life and Jieun's upcoming job interview.

22. Jieun comes back to the apartment. Her sister Jihye's text appears in a pop up message. The text is about Jihye needing money for her school. Without opening the pop up message, Jieun just directly replying that she will work for it.

23. 3 days after the talk on the rooftop, Jieun is having a job interview yet she still meets Jihoon before the interview. They are meeting again in the same café near Jieun's apartment.

24. Jihoon complains again about Sohyun not returning his messages while Jieun tries hard to keep an eye for each of them: one for Jihoon and another one for the things she prepared for the interview.

25. Jihoon is getting a little impatient and demands more attention and Jieun starts nagging at him. She tells him that Jihoon needs to be a little more mature sometimes and tells him to solve their own problem.

26. To their surprise, it turns out that Jieun calls Sohyun secretly to meet in the same café at the time when she needs to leave so that Sohyun and Jihoon would talk everything out.

27. Jieun leaves them both to run for her interview. Along the way, she practices, practices and practices for her interview. A lot of people are staring at her but she does not care.

28. A day after the interview. Jieun starts cleaning out her apartment. She takes out all the trash, tidying her table and living room, washing her laundry and the dishes.

29. Her phone rings. It is Jihoon calling. 
30. She takes the call. Not long after the takes the call, she hears someone is coming to her apartment. Sohyun is coming into her apartment. She goes in as Sohyun knows Jieun's apartment code already and that she knows that Jieun is home already. Sohyun is crying, feeling frustrated of her own feelings.

31. Jieun asking Sohyun what is wrong. Sohyun then tells everything about what she and Jihoon have been arguing about.

32. Jieun scolded Sohyun for being selfish. Jieun told Sohyun that she should have been more understanding towards Jihoon.

33. A flashback of Jihoon, Jieun and Sohyun at the beach. The flashback shows that Jihoon is actually interested in Jieun. But because of Jieun's principal, they cannot be together while Jieun also likes Jihoon.

34. Back to the present, Jieun is broken down. She feels so sad and broken.

35. Jieun receives a phone call from Jihye, her sister.

36. The phone call says that Jiseok, her youngest sibling is sick and keep calling Jieun's name. Jihye kind of half-forcing Jieun to go to Ulsan, saying that she would repay the bus money Jieun use for the bus.

37. Jieun goes to Ulsan that night using a night bus.

38. In the bus, Jieun is looking at a picture of her and her siblings when they were younger.

39. The moment flashbacks to when Jieun is about to go to college. That time, Jieun said that she would make her dad and siblings proud.

40. Back to the present, Jieun realized that it's actually kind of impossible for the moment. She decides to just forget about it for a moment and then goes to sleep in the bus.

41. Morning after, Jieun goes directly to her house. She knocks on the door and finds her sister, Jihye. They hug each other, expressing how they miss each other.

42. Jihye mentions about how their brother is still a little unwell, she also tells Jieun to go to their brother's room to see him, also to say hi to their Father there.

43. When the word "Father" is mentioned, Jieun can't help but get anxious. She thinks that her father would get mad to her because she fails to fulfill the family's wish. But, it turns out that her father is just happy that Jieun is coming back.

44. Jieun apologizes to her family since she is not yet able to fulfill the family's wish.

45. It turns out that her Father is not that mad about her not getting a job yet. Her sister also mentions about the amount of money she needed for school.

46. It turns out that Jihye is also working part time to be able to support herself and her school supplies.

47. Jieun get touched to hear all that. She is about to say something when her phone rings.

48. Jieun takes the call.

49. It's from the company she got interviewed in couple days before. She got called for a second interview.

50. Jieun is of course, beyond happy. She comes back to the house and tells everyone the good news. Jihye, Jiseok and Father are all glad to hear that.

51. Not too long after Jieun continues eating, her phone vibrates again. This time, it's from Jihoon.

52. Jihoon telling Jieun that Sohyun has agreed to spend more time with Jihoon's family and that they have sorted things out. Jihoon is deeply thanking Jieun.

Jieun smiles and seems contented, she no longer feels heavy when Jihoon is mentioning about her relationship with Sohyun anymore.

\section{CONCLUSION}

I learned a lot of things through this project. I learned how hard it is to make something cliché interesting, and to keep audience's eye on my works. Alongside the making of this work, I discussed a lot with my professor and faced a lot of struggles. I was forced to think of what would be interesting for the audience, and also how to keep my project has more actions than dialogues, which is the hardest because here I focus more on the dialogues.

Aside from that, I also face difficulties in revising the script because it was nothing near what I thought it would be. Writer's block affected me a lot and during those times, it was hard. 
Especially when I gave my professor my revision and he thought that my work is still "talkie" in which he meant that my works still has a lot of dialogues in it, and it could be boring for the audiences.

, through this project I learned a lot that audiences is the king. I learned that we need to consider the audiences the most through our dialogues, movements, mise-en-scene, etc. We need to focus on the story and the audience at the same time that we cannot let the audience feel bored of our works; and I think that is the most lesson I learned in this project.

As I work on this project, I learn that love itself has a lot of dimension in it, not only in the genre of love itself, but also the things surrounding it. Love does not come by itself, but love comes from us, to us and surrounding us, as a human being. Love comes with a lot of problems and struggles. One of them is whether to choose between self and others. In this case, I would like to explore a lot more dimension of love in order to support this story more as well to develop the story even more if possible.

\section{REFERENCES}

Buffam, Noelle. (2011) Drama.

Retrieved September 27, 2017, from https://thescriptlab.com/screenplay/genre/952-drama/

Cooper, Matthew. (2012). Retrieved May 5th, 2017, from https://www.slideshare.net/coopermatt62/codes-and-conventions-of-drama

Dercksen, Daniel. (2015) Genre and Genre Conventions. Retrieved June 27, 2017, from writingstudio.co.za/what-type-of-story-are-you-writing/.

Drama (2011). Retrieved September 16, 2017, from https://thescriptlab.com/screenplay/genre/952drama/

French, Christy Tillery. (2013). Literary Fiction vs Genre Fiction. Retrieved September 26, 2017.

Goris, An. (2014). Hidden Codes of Love: The Materiality of the Category Romance Novel. Retrieved May 5, 2017, from https://belphegor.revues.org/616

Gray, Charlotte. (2011). Conventions of the romance genre. Retrieved May 20, 2017, from http://charlottegraya2media.blogspot.co.id/2014/09/conventions-of-romance-genre.html

McLeod, S.A. (2017). Erik Erikson. Retrieved April 20, 2017, from www.simplypsychology.org/ErikErikson.html /

Royston, Tom. (2014). Conventions of the Romance Genre. Retrieved May 25, 2017, from https://prezi.com/8geyfojgju8c/conventions-of-the-romance-genre/

Sternberg, Robert. (1986) Retrieved September 23, 2017, from https://www.psychologytoday.com/blog/handy-psychology-answers/201102/the-psychologylove

Sternberg, Robert. (1986) A Triangular Theory of Love. Retrieved October 19, 2017.

Sternberg, Robert J. (2007). "Triangulating Love". p. 332. Retrieved October 19, 2017.

Williams, Clyde. (n.d.). Identifying Genres - Codes \& Expectations. Retrieved May 10, 2017, from http://www.clydewilliams.com/page5/page22/page22.html

Wyatt, Neal. (2016). Core Collections in Genre Studies: Romantic Fiction 101. Retrieved May10, 2017, from https://journals.ala.org/index.php/rusq/article/viewFile/3739/4073 